\title{
ANALISIS DEKONSTRUKTIF TERHADAP RADIKALISME ISLAM: Dari Nalar Islam Pusat Menuju Identitas Islam Pribumi
}

\author{
Ahmad Lutfi \\ STAIN Sunan Ampel Ponorogo \\ Ahmadlutfi636@gmail.com
}

\begin{abstract}
Abstrak
Arus modernitas bangsa Barat ke berbagai belahan dunia, memicu reaksi dari tubuh umat Islam. Reaksi tersebut terpola menjadi tiga model pergulatan wacana pemikiran. Pertama, merujuk teks-teks dasar al-Qur'an. Kedua, merujuk seluruh tradisi yang muncul pada era kenabian sebagai bentuk aplikasi yang pertama. Ketiga, merujuk pada keseluruhan produk dari interaksi tripartit antara umat Islam, teks-teks keagamaan dan situasi yang melingkupinya. Kelompok yang pertama yang menjadikan teks-teks dasar al-Qur'an sebagai satu-satunya otoritas epistemologis disebut Islam fundamentalis. Kelompok kedua yang mencakupkan tradisi sebagai bentuk aplikasi yang pertama disebut Islam tradisionalis. Dan kelompok yang ketiga dengan pendekatan tripartitnya selanjutnya disebut Islam liberal. Makalah ini akan memberikan suatu koreksi terhadap desain pemikiran yang sudah mengglobal pada diri Islam fundemantalis dengan proyek universalisme Islamnya dan akan menggunakan model pendekatan studi postkolonialis. Pembahasan dalam studi postkolonial ini akan dibagi menjadi lima sub pembahasan. Pertama, mengenali akar-akar hegemonik Islam fundamentalis. Kedua, penerapan travelling theory tahap pertama. Ketiga, penerapan travelling theory tahap kedua. Keempat menggambarkan bentuk identitas etnis pada Islam tradisional. Dan kelima, faktor problematika dari Islam fundamentalis dan Islam tradisionalis.
\end{abstract}

Abstract

DE-CONSTRUCTIVE ANALYSIS TOWARD ISLAMIC RADICALISM: FROM THE ISLAMIC- CENTERED REASONING TO THE NATIVE ISLAMIC IDENTITY. The flows of Western modernity penetrating into various parts of the 
world have triggered respons from the Muslim world. The respons occur in the form of intellectual discourses aroused from three groups, namely : First, those who refers to the basic texts of the Koran; Second, those who incorporates the basic texts of the Koran with the whole tradition that emerged in the prophet era; Third, those who refers to the overall products of tripartite interaction between Muslims, religious texts and surrounding circumstances. The first group, who uses the basic texts of the Koran as the sole authority of epistemology, is called Muslim fundamentalist. The second group, who incorporates the basic texts of the Koran with the the prophet's tradition as the first application form, called the Muslim traditionalists. While the third group, who uses the tripartite approach, herein after is called liberal Muslim. This article gives a correction to the fundamentalist Muslims which have been spread around the muslim world with their Islamic universalism project. The approach used here refers to the study of post-colonial model which highlights five things, i.e : First, the hegemonic. roots of Muslim fundamentalists; Second, the implementation of the first phase of traveling theory. Third, the implementation of the second phase of traveling theory; Fourth, the form of ethnic identity in traditional Islam; And, fifth, the problems of fundamentalist and traditionalist Muslims.

Kata Kunci: Universalisme Islam; Postkolonialis; Travelling Theory; Identitas Etnis

\section{A. Pendahuluan}

Adanya pengeboman gedung World Trade Centre di Pentagon yang terjadi pada 11 September 2001 menjadi titik pemicu bagi para pengamat dan peneliti, baik itu peneliti Timur dan Barat dan juga yang hidup di Asia tenggara seperti Indonesia, untuk memberi arti baru pasca tragedi itu. Arti baru itu adalah lahirnya babak baru dalam sejarah dunia, pasca runtuhnya ideologi besar dunia, Sosialisme, yang menjadi lawan bagi Kapitalisme. Babak itu adalah babak agama dan itu adalah Islam. ${ }^{1}$

Para pengamat dan teoritikus sosial membagi pergulatan dalam pemikiran agama itu menjadi tiga model wacana ke-Islaman yang mempunyai karakteristik yang berbeda satu sama lain. Pertama, merujuk teks-teks dasar al-Qur'an dan mengenyampingkan peran

${ }^{1}$ Ahmad Norma Permata (ed), Agama dan Terorisme, (Surakarta: Muhammadiyah University Press, 2006). Buku ini mengulas tentang teroris dikaitkan dengan persoalan keadilan dan persoalan doktrin inti ajaran. Analisis tentang masalah keadilan dengan menggunakan perspektif Durkheim sementara doktrin dikaitkan dengan teori sosiologi Weber. 
rasionalis-kritis. Kedua, merujuk pada al-Qur'an dan menggunakan seluruh tradisi yang muncul pada era kenabian sebagai bentuk aplikasi penafsirannya (al-Qur'an, al-Hadis, Ijma', dan Qiyas). Ketiga, merujuk pada keseluruhan produk dari interaksi tripartit antara umat Islam, teks-teks keagamaan, dan situasi yang melingkupinya. Interaksi antara tiga kelompok pemikiran itu saling menegaskan diri sebagai model bagi keberagamaan di tengah kehidupan berbangsa. Karena adanya "saling menegaskan diri" itu sehingga tak jarang juga terjadi benturan dan saling menyingkirkan. Kelompok pertama seringkali mengambil posisi berhadap-hadapan, bahkan tak jarang sikapnya melawan terhadap kelompok ke dua dan ketiga. ${ }^{2}$

Pemikiran Islam yang ada pada model pertama, adalah kelompok Islam yang merujuk pada banyak organisasi keagamaan, yang punya corak radikal, militan, dan ekstrim. Disebut radikal karena mereka ingin menjadikan Islam sebagai ideologi dan ingin mengembalikan pada zaman sebagaimana Islam itu dilahirkan, masa Arab pertengahan. Kelompok Islam ini disebut sebagai Islam radikal dan ingin menjadikan Islam bersih dari percampuran di luar apa yang telah dibentuk oleh Islam awal. Sedangkan kelompok kedua, punya sikap berlawanan dengan Islam pertama. Mereka lebih moderat dengan mengakomodasi budaya setempat dengan asumsi bahwa kebangkitan itu harus lahir dari corak yang berbeda dengan corak yang telah digariskan di masa awal. Kebangkitan haruslah

${ }^{2}$ Tipologi wacana pemikiran ini saya pinjam dari Adonis yang nama aslinya Ali Ahmad Said. Ia menggunakan tipologi itu untuk menggambarkan pergulatan pemikiran yang terjadi di dunia Arab. Namun dari sisi relevansinya terhadap kajian ini, yang khusus mengkaji bumi tanah air Indonesia, masih ada. Misalnya untuk mengidentifikasi gerakan-gerakan politik berbasis ideologi agama yang cukup marak di akhir-akhir ini serta menggunakan al-Qur'an dan al-Hadis sebagai otoritas epistemologi satu-satunya. Kemudian gerakan pemikiran yang menggunakan otoritas nalar (akal) dan juga tidak mengenyampingkan al-Qur'an dalam epistemologinya. Dan juga ada kelompok yang mengambil posisi tengah antara kelompok yang pertama dan yang kedua. Gerakan Islam dengan orientasi politik atau gerakan politik disebut sebagai Islamisme, sementara gerakan pemikiran yang menggunakan akal sebagai media untuk mencari kebenaran disamping juga al-Qur'an disebut sebagai Islam lokal. Mengenai tipologi pemikiran di atas lihat Adonis, As-Ṣābit wa al-Mutaḥawwil: Bahis fi al-Ibda' wa al-Itba' 'inda al-Arab yang sudah di terjemahkan ke bahasa Idonesia dengan judul Arkeologi sejarah pemikrian Arab Islam, (Yogyakarta: LkiS Group, 2007), h. viii. 
bercorak dan berpijak pada budaya setempat. Kelompok kedua ini selanjutnya disebut sebagai Islam tradisionalis. Kelompok yang ketiga mencoba mengintegrasikan diri dengan Barat dan segenap perkembangan keilmuannya. Kelompok ketiga ini kemudian disebut sebagai Islam liberal. ${ }^{3}$

Tiga model wacana pemikiran dan gerakan tersebut "Islam radikal", "Islam tradisional" dan "Islam liberal" yang menjadi model Islam yang lahir dari rahim bumi Indonesia, sedang mengalami masalah penting. Keberadaan Islam model pertama seringkali menyerang dan menyingkirkan. Misalnya, Islam model kedua dianggap sebagai kurang Islami, campur dengan "lokalitas", tahayul, bid'ah, khurafat dan kalau perlu harus diperangi dan di-Islamkan lagi olehnya. Sedangkan pada Islam liberal dianggap sebagai “sekuler”, pro Barat, kufur dan terjajah dan harus disadarkan dari keterjajahanya. Di antara problem itu antara lain di berbagai wilayah seringkali terdengar isu tentang konflik dan ketegangan antar penganut model pemikiran beragama. ${ }^{4}$ Di satu sisi, muncul istilah penyesatan dan pengkafiran antar kelompok, klaim diri sebagai Islam yang murni dan otentik. Di sisi yang lain, muncul alternatif-alternatif seperti pemberlakuan syari'at Islam, negara Islam atau khilafah Islamiyah. Dari kelompok Islam radikal ini pemahaman tentang agama dibelah menjadi dua, yakni Islam yang selamat dan itu hanya dirinya dan Islam yang tidak selamat alias kufur dan itu Islam di luar dirinya. ${ }^{5}$

${ }^{3}$ Istilah-istilah seperti di atas memang bisa memicu kontroversi. Misalnya apa batasan epistemologi yang membatasi masing-masing kelompok juga masih bisa diperdebatkan. Oleh karena itu penulis menggunakan istilah di atas hanya sebagai alat bantu bagi analisis untuk memudahkan dalam pemahaman permukaan. Adapun beberapa praktek penggunaan alat bantu analisis ini kami dasarkan pada Charles Kurzman, "Pengantar Islam Liberal dalam konteks Islaminya”, dalam Charles Kurzman (ed), Wacana Islam Liberal; pemikiran Islam Kontemporer Tentang Isu-Isu Global, (Jakarta: Paramadina, 2001), h. xiii.

${ }^{4}$ Data tentang beberapa konflik yang terjadi di beberapa wilayah di Indonesia ini kami dasarkan dari beberapa kejadian yang dirangkum dalam Wahid Institute, Seri Agama dan Konflik 2; Agama dan Pergeseran representasi: Konflik dan Rekonsiliasi di Indonesia, (Jakarta: The Wahid Institut, 2009). Sebagian wilayah memang belum terjadi konflik fisik namun punya potensi besar bagi lahirnya chaos. Wilayah itu antara lain adalah Ponorogo di desa Klepu Sooko Kabupaten Ponorogo.

${ }^{5}$ Istilah kufur dimaknai sebagai sekelompok orang yang tidak menerapkan al-Qur'an dan al-Hadis. Hal ini didasarkan pada pemahaman mereka bahwa al-Qur'an dan al-Hadis adalah "tali” persambungan manusia dan Tuhan. Jika manusia tidak 
Dari sikap konfrontatif dan klaim akan "otentisitas” yang ada pada diri kelompok Islam radikal ini, lahir gerakan-gerakan sosial agama yang kian menjamur di era belakangan ini. ${ }^{6}$ Atas nama otentisitas dan Islam, mereka ingin mengambil paket Islam zaman pertengahan sebagaimana seperti di zaman Nabi saw untuk dipanggungkan kembali pada hari ini. ${ }^{7}$ Dengan alasan, zaman itu Islam telah menjadi supremasi dunia, maju, menguasai, dan menang. Sebaliknya, mereka memandang Islam model kedua dan ketiga sebagai Islam yang berada dalam keadaan kalah, tertindas, terbelakang, dan lainya dari cepatnya laju kemajuan peradaban Barat serta modernitas yang menyertainya.

Sikap konfrontatif oleh kelompok Islam radikal, serta menganggap Barat dan proyek modernitasnya berwajah kolonial, dan cara pandangnya pada Islam lokal Islamnya telah tercampuri bid'ah, takhayul, dan khurafat dibarengi dengan upaya menegaskan diri sebagai kelompok Islam yang paling otentik itu, mereka

menggunakan tali itu berarti dia telah lepas hubunganya dengan Tuhan. Dengan itu mereka adalah kufur. Dasar dari pemahaman ini adalah ayat al-Qur'an yang artinya "barang siapa menghukumi tidak dengan hukum Allah maka mereka itu adalah kafir". Dengan demikian maka negara juga harus berdasarkan al-Qur'an dan alHadis sebagai sumber dari segala sumber hukumnya. Lihat Taqiyuddin an-Nabhani, Niz̄ām al-Islam. Terjemahan dengan judul Sistem pergaulan Dalam Islam, (Jakarta: HTI Press, 2006) h. 100-127.

${ }^{6}$ Tentang model-model gerakan Islam radikal yang menjadi trend di tahun belakangan ini, misalnya gerakan Islam transnasional. Di antara kelompok Islam yang tergabung dalam Islam transnasional ini antara lain PKS, FPI, FKAWJ, FUI, MMI, KPPSI, Laskar Jihad, HTI dan JI. Kemudian ada model gerakan Islam "non mainstream” yang masih tergabung dalam Islam Transnasional, seperti Ahmadiyah, dan aliran Islam dari Indonesia sendiri yang dicap sesat seperti, Salamullah dan al-Qiyādah al-Islāmiyah. Lihat Ahsin Wijaya, Menusantarakan Islam; Menelusuri Jejak Pergumulan Islam yang tak Kunjung Usai di Nusantara, (Yogyakarta: Nadi Pustaka, 2012), h. 141.

${ }^{7}$ Untuk gerakan Islam transnasional ini terbagi menjadi dua kelompok. Pertama, adalah Islamisme, dimana orientasinya adalah menjadikan Islam sebagai ideologi (mabda'). Gerakan ini bersifat politik. Kedua, salafisme, di mana orientasi gerakannya bersifat permbersihan Islam dari tradisi lokal. Tipologi Islamisme dan Salafisme ini di dasarkan pada makalah pelatihan Ideologi yang diadakan oleh team Litbang NU cabang Ponorogo yang dilaksanakan pada tanggal 18-19 Mei 2013 oleh Ahsin Wijaya, "Peta Gerakan Islam Di Indonesia”, h. 1 dan 2. 
menyebut dirinya sebagai model Islam yang selaras dengan proyek kebangkitan (nahdlah). ${ }^{8}$

Dari sini, sebenarnya ada aspek yang terselubung dalam kata "kebangkitan" ini. Aspek terselubung yang pada diri para Islam radikal, dia membagi antara "Islam pusat" dan "Islam periferal". Islam pusat adalah Islam yang ada di masa Nabi Muhammad saw dan secara geografis berada di timur tengah. Argumentasi sederhananya, Islam di masa itu adalah Islam yang menang dan menempati supremasi dunia. Jadi untuk menjadi bangkit dan menang Islam harus kembali ke "arena pusat". Sementara Islam di luar masa itu adalah Islam periferal. Islam ini adalah Islam yang tidak asli, dan jauh dari tipe ideal. Singkatnya, ada dimensi tak terkatakan dalam proyek itu. Dimensi itu adalah gerak untuk meng“universalkan” Islam yang "pusat" dan menggunakan standar itu untuk dipakai pada wilayah yang lain, termasuk di bumi Nusantara ini. Dengan adanya dimensi terselebung itu maka ketegangan yang terjadi antara Islam radikal dan Islam di luarnya pada hakekatnya adalah ketegangan tentang model keberagamaan yang harus dipakai sebagai standar hari ini berhadapan dengan Barat. Karena Islam model hari ini terpuruk dan kalah maka untuk menjadi menang harus kembali pusat dan Islam yang ada pada hari ini dan berada di sini harus diberangus, diracik ulang, dan lebih penting lagi "dipusatkan".

Dengan demikian, demi adanya kebangkitan Islam itu, mereka ingin membakukan sebuah standar, yang bisa dipakai untuk keluar dari jeratan masa sekarang yang kalah, untuk melahirkan kebangkitan.

Dalam kajian ini, akan diupayakan memberikan satu koreksi atas desain global yang mengatasnamakan misi "kebangkitan"

${ }^{8}$ Istilah "kebangkitan" seringkali digunakana semenjak tahun 1970-an untuk menyebut gerakan Islam radikal. Hal ini dipicu oleh beberapa faktor. Pertama, adanya kekecewaan yang dirasakan oleh masyarakat terkait dengan ideologi yang dianut dan suksesnya gerakan-gerakan Islam transnasional dalam merebut masa dan menawarkan diri seolah tampil sebagai alternatif terhadap bobroknya ideologiideologi besar. Kedua, mereka sibuk dalam merespon inisiatif pihak-pihak lain sembari menawarkan aspirasi ganda kalangan profesional modern dan masyarakat muslim yang menghendaki partisipasi besar dalam proses politik untuk terwujudnya masyarakat yang Islami. Lihat John L. Esposito dan John O. Voll, Demokrasi Di NegaraNegara Muslim; Problem dan Prospek, (Bandung: Mizan, 1999), h. 5. 
tersebut. Koreksi ini akan diarahkan pada produksi pengetahuan dan juga standar kebenaran yang coba "dipakemkan". Pakem itu akan dipaksakan pemberlakuanya pada komunitas Islam tradisional dan liberal dengan harapan bisa mengikuti suatu desain ala mereka tentang isu "universalisme Islam". ${ }^{9}$ Isu itu berisi antara lain, mengarahkan umat komunitas Islam untuk menjadi muslim yang taat, bagaimana menjadi muslim yang ideal, otentik dan asli sesuai dengan Nabi, tapi tentunya sesuai dengan masa nabi ala selera mereka. Dan kalau perlu, umat Islam hari ini harus memerangi Barat yang kolonialis dan faham Islam yang mengabsahkan dan mengadopsi lokalitas lainya yang mengancam pemberlakuan "Universalisme Islam" tersebut.

Tulisan ini hanya akan mengarahkan pada koreksi pengetahuan Islam radikal yang berkaitan dengan konstruksi pengetahuannya, yang akan melakukan misi kebangkitan dengan mengusung konsep universalisme Islam. ${ }^{10}$ Tela'ah terhadap konstruk

${ }^{9}$ Konsep universalisme dalam hal ini tidak sama sebagaimana dalam istilah Nurcholis Madjid, dimana penggunaan istilah universal dalam kaitannya dengan titik temu antara agama-agama Samawi dalam masalah inti ajaran yakni Tauhid. Nurcholish Madjid, Islam Doktrin dan Peradaban (Jakarta: Paramadina, 2005), h. 425. Juga bukan dalam Istilah yang digunakan oleh Harun Nasution dalam buku Islam Rasionalnya, dimana konsep universal diartikan sebagai kenabian Muhammad yang diutus oleh Allah kepada semua suku di Arab. Kemudian dia mengaitkan universalitas itu dalam kaitanya dengan ilmu pengetahuan yang telah dihasilkan oleh umat Islam, yang meliputi ilmu agama dan sains yang keberlakuanya bersifat universal serta beberapa ajaran dalam Islam seperti musyawarah yang juga dipakai oleh siapapun dan dalam tempat serta situasi apapun. Harun Nasution, Islam Rasional (Bandung: Mizan, 1996), h. 32-34. Bukan pula istilah universal ini sebagaimana digunakan oleh Abdurrahman Wahid dalam konsepnya tentang "pribumisasi Islam”, dimana dia menggunakan istilah universalisme dalam kaitanya dengan manifestasi ajaran fiqh, akhlak, dan tasawuf yang menampilkan kepedulian besar terhadap kemanusiaan. Lihat Ahsin Wijaya, Menusantarakan Islam; .... h. 164. Lihat juga Abdurrahman Wahid, Islam Kosmopolit: Nilai-Nilai Indonesia dan Transformasi Kebudayaan, (Jakarta: The Wahid Institut, 2007), h. 3. Adapaun yang kami maksud dengan universalisme dalam hal ini adalah sebagaimana dipakai oleh Edward Said yang mengatakan," the attempt to hold to universal and single standard as a theme plays an important role in my account of the intellectual. Or rather the interaction betwen universality and the local, the subjective, the here and now". Lihat Edward Said, Representations of the Intellectual the 1993 Reith Lectures, (New York: Vintage Books, 1996), h. xiii.

${ }^{10}$ Istilah Universalisme Islam dalam hal ini adalah upaya kaum Islam radikal dalam mengusung Islam awal yang ada pada zaman Nabi saw untuk diuniversalkan 
pengetahuan Islam radikalis ini akan menggunakan pendekatan model studi postkolonialis dengan tujuan untuk memberikan suatu "identitas konseptual" terhadap makna hegemonik pada Islam radikal. Di samping itu juga akan menyandingkan dengan "identitas etnis" pada Islam tradisionalis. Sedangkan sesi yang membahas Islam liberal tidak kami ulas karena untuk lebih memfokuskan pembahasan. Adapun pembahasanya akan dibagi dalam beberapa sub pembahasan. Pertama, akan menyingkap konsep hegemonik universalisme Islam. Kedua, penerapan traveling theory tahap pertama dan kedua. Ketiga, identitas Etnis Islam Nusantara atau Bentuk dari kultur lokal Islam Tradisional, dan keempat, mendeskripsikan faktor utama dari problema antara otoritas Islam radikal dan Islam tradisional.

\section{B. Menyingkap Konsep Hegemonik Dalam Universalisme Islam}

Pembahasan dalam studi postkolonial adalah siapa yang menjadi subyek dan mengobyektifikasi apa. Dengan teori ini, "Islam tradisional” yang digambarkan oleh Islam radikal sebagai objek, kini berubah menjadi subyek dan memperlakukan "Islam radikal" sebagai objek. Dalam wacana Islam radikal, yang menjadi objek adalah Islam tradisional sedangkan dalam wacana postkolonial atau dekolonisasi ini, yang menjadi objek berbalik menjadi Islam radikal atau Islam ala Arab. Menurut Tiffin dan Lawson, kolonialisme (seperti rekannya rasisme) adalah sebuah formasi wacana, dan sebagai ruang pengoperasian wacana maka ia mempertanyakan (interpellat) subjeksubjek kolonial dengan memasukkan mereka ke dalam suatu sistem penggambaran. ${ }^{11}$

Pada hakekatnya wacana (discourse) akan membentuk subyek dan akan mengarahkannya untuk melihat dan mengkonstruksikan peristiwa tertentu. Hasilnya, dia akan memasukkan narasi peristiwa tersebut ke dalam bentuk yang bisa dikenali oleh

dan dijadikan sebagai "pakem" namun dalam versi pengetahuan mereka. Jadi pemakaian "me" pada istilah universalisme, yang umumnya pemakaian "me" itu terkandung makna ideologi, karena Islam awal yang diusung tersebut merupakan Islam awal dalam konstruksi pengetahuan Islam radikal.

${ }^{11}$ C.Tiffin dan A. Lawson, De-scribing empire, Postcolonialism and Textuality (London and New York: Routledge,1994), h. 3. 
kebudayaan tertentu. ${ }^{12}$ Dengan alur demikian ini maka subyek akan terjaring dengan sendirinya dengan makna yang dibuat dari hasil konstruksinya sendiri dan mempengaruhinya dalam mengkategorikan dan menafsirkan pengalaman dan peristiwa. ${ }^{13}$ Dia akan dengan serta merta mengikuti struktur yang tersedia dan susah keluar dari struktur diskursif yang sudah dibentuknya sendiri. Struktur diskursif tersebut adalah bangunan besar dan secara sistematis batas-batas itu berbentuk sebuah episteme. ${ }^{14}$ Nah dengan episteme inilah subyek melakukan obyektifikasi pada the other (liyan). Misalnya dalam Islam tradisional dikenal dengan pentingnya untuk mengadopsi budaya lokal serta segenap ide-ide yang menyertainya seperti, ritual dan upacara adat serta pengawinan hukum Islam dengan adat setempat. Ide ini dianggap sebagai langkah dalam meletakkan Islam agar sesuai dengan bumi yang dipijaknya dalam melakukan kebangkitan. Namun lain halnya dalam pandangan Islam radikal. Kerja pengawinan Islam dengan lokalitas tersebut malah dipandang sebagai ide "bid'ah" yang harus dibendung dan dimurnikan. Ada cara pandang yang berbeda karena perbedaan konstruksi makna pada masing-masing antara Islam tradisional dan dan Islam radikal. Dalam pandangan Islam radikal, ide budaya lokal adalah konsep yang menjadikan Islam tercampuri dan tidak murni, sementara ritual dianggap cacat karena menjadikan Islam tidak seperti asalnya. Segenap retorika dikonstruksi agar ditolaknya Islam

\footnotetext{
${ }^{12}$ Dalam masalah ini penulis terilhami konsep Ferdinan de Sausure, peletak dasar teori linguistik modern, tentang masalah signifiant dan signifie. Signifiant adalah ilmu tentang tanda dan signifie adalah konsep yang dimaksudkan dalam tanda. Ketika seseorang berbicara menunjuk pada suatu obyek tertentu maka yang dimaksudkan adalah konsep yang tergambarkan dalam fikiran sang pembicara. Jadi signifie adalah aspek mental dari bahasa. Maka ketika seseorang sedang bercerita tentang suatu fakta tertentu, maka sebenarnya yang diceritakan adalah gambaran konsep yang telah terpatri dalam benak fikirannya. Jadi gambaran tentang peristiwa yang dituturkan oleh sang pembicara bukanlah fakta apa adanya, tapi sudah mengalami proses pembentukan narasi cerita yang dibentuk oleh nalarnya. Lihat ulasan tentang pemikiran ferdinan de Sausure dalam Karl bertens, Filsafat Barat Abad XX Prancis jilid II, (Jakarta: Gramedia Pustaka Utama, 1996), h. 179-184.

${ }^{13}$ Makalah dari Kris Budiman,"Hermeneutika, Kebudayaan Sebagai teks: Persoalan Etnosentrisme Dalam Interpretasi, h. 1-2. Makalah ini diambil dari modul pelatihan LkiS.

${ }^{14}$ Eriyanto, Analisis Wacana; Pengantar Analisis Teks Media, (Yogjakarta: LKiS, 2005), h. 75.
} 
tradisional. Retorika yang keluar dari pandangan yang berbeda dalam memandang obyek dalam kasus seperti itulah episteme bekerja.

Ketika wacana tentang Islam radikal dan Islam tradisional ditulis dalam sebuah teks, maka ia telah berubah menjadi teks yang berbicara dengan dirinya sendiri dan pembacanya tanpa merujuk pada situasi awal yang mengitari sekitar dirinya. ${ }^{15}$ Inilah yang disebut otonomi semantis dalam pandangan Paul Recoeur. Dengan kata lain, menurutnya, teks kini memasuki dunianya sendiri dan dunia tersebut tidak dibatasi oleh wujud realitas awal lahirnya teks tersebut. Realitas pembentuk teks itu tidak bisa diamati secara langsung sebagaimana ketika dua orang saling bertutur tentang suatu hal. Dalam teks tertulis,"the world is totality references opened up by texts" ${ }^{16}$ Dengan penjelasan itu maka teks adalah totalitas yang bisa menampung segenap realitas. Apabila teks itu dipakai untuk berbagai realitas wujudi dalam wilayah yang berbeda maka teks berbicara tentang dunia-dunia yang serba mungkin. Ia punya cara-cara dan kemungkinan untuk mengarahkan dirinya (oneself) ke dalam dunia tersebut. Maka realitas aslinya pun pada giliranya bersifat "non situasional" (melampui realitas). Wujud dan hidupnya membentang lebih lama dari rujukan lingkup kebudayaan aslinya dan sekaligus menawarkan dirinya "possible mode of being". ${ }^{17}$ Maka di sini kita akan memasuki dunia yang diciptakan oleh teks pada level lain yang justru lebih fundamental: a proposed world. Pada awalnya suatu wacana berbicara dan bertitik tolak dari sebuah realitas tertentu, namun ketika ditulis wacana tersebut lalu menampilkan realitas pada level kedua: realitas yang bukan hanya memutuskan dirinya dengan realitas yang pertama tapi juga malah melangkah

${ }^{15}$ Islam itu sendiri sebenarnya lahir sebagai produk lokal yang kemudian diuniversalisasikan dan ditransendensi sehingga kemudian menjadi Islam universal. Yang saya maksud dengan Islam sebagai produk lokal adalah Islam lahir di Arab, tepatnya daerah Hijaz, dalam situasi Arab dan pada waktu itu ditujukan sebagai jawaban terhadap persoalan-persoalan yang berkembang di sana. Hal ini memang kemudian dikonstruksi sebagai potret dari kecenderungan global. Lihat wawancara antara Abdul Munir Mulkan dengan Ulil Abshar Abdala tema "Islam adalah Produk Lokal” yang muat di situs internet pada tanggal 14 April 2002 .

${ }^{16}$ Paul Recoeur, Hermeneutics and The Human Sciences: Essays on language, action, and intepretation, terj. John B. Thompson, (Cambridge: Cambridge University Press, 1984), h. 177.

${ }^{17}$ Ibid. 
lebih jauh. Dalam genggaman pembaca ia menciptakan realitasrealitas baru dan dunianya sendiri. Misalnya teks-teks universalisme Islam dalam wacana Islam radikal lahir dalam realitas sosial kehidupan beragama di Indonesia, maka ia tidak berbicara tentang realitas tersebut apa adanya seperti zaman ketika agama itu muncul. Ia justru mereproduksi kembali secara diskursif (yakni dunia-dunia baru). Dalam arti ketika berbicara tentang realitas yang pertama, yakni kondisi sosial dimana ia lahir, teks tidaklah berbicara melebihi kemampuannya dalam mencover detil-detil realitas tersebut: dalam proses perumusan wacana ia mengangkat satu sisi dan membuang sisi lainya, menonjolkan satu unsur di samping juga mendiamkan unsur lainya, mendahulukan aspek tertentu dan mengedepankan aspeklainya. Ketika di tangan sang pengarang maka ia mencerminkan kadar kemempuan sang pengarang untuk tunduk dan terikat pada hukum diskursif tersebut: mengangkat satu dengan membuang yang lain dalam rangka meyakinkan pembaca. ${ }^{18}$ Maka realitas yang di repro (realitas ke dua) pun pada akhirnya sudah jauh berbeda dengan realitas pertama yang umurnya lebih pendek dan cuma "sekali hidup" itu dibandingkan dengan realitas baru tersebut. Apabila wacana mengungkap pemikiran tertentu maka pemikiran tersebut juga tunduk pada proses diskursif: ada yang dibuang, ada pula yang diangkat, ada yang didiamkan, dan ada pula yang disebutsebut.

Itu berarti, pemikiran apapun yang diformulasikan dalam sebuah wacana, dan dalam suatu bahasa, pada akhirnya melibatkan unsur-unsur psikologi, seperti hasrat keinginan, harapan, perasaan, was-was, dan takut. Elemen-elemen semacam inilah yang disebut Foucault sebagai bagian integral dari "its unity, its characterization and the laws of its formation" dari suatu wacana; singkatnya sebagai "its formative element"19 dan itu punya dampak besar bagi analisa atas Islam fundamentalis "constructs and deconstructs it self, tells and untells it self".

${ }_{18}$ Penjelasan tentang struktur wacana dan proses diskursif ini kami dasarkan pada Muhammaed Abed al-Jabiri, al-Khițāb al-'Arab al-Mu'ạsir: Dirāsah TahTiliyah Naqdiyah (Beirut: Markāz Dirāsah al-Wihdah al-'Arabiyah, 1992), cet. IV, h. 10-13.

${ }^{19}$ Michel Foucault, The Archeology of Knowledge; terjemahan A.M. Sheridan Smith (London: Tavistock, 1972), h. 68. 
Dalam kontek membaca wacana Islam radikal ini, kita bisa belajar dari Arkoun ketika melakukan pelacakan terhadap ide nalar Barat yang mengalami universalisasi pada nalar Eropa abad 19 yang ekspansioniskenegara-negarajajahanatasnama"MisiPemberadaban" (Civilizing mission $)^{20}$. Arkoun menyebutnya, berpretensi obyektif dan standar bakunya dianggap normatif. Dengan kata lain, standarisasi dan obyektifikasi selalu dilekatkan dengan Universalisasi. Menurut Edward Said, the universal is always achieved at the expense of the native ${ }^{21}$ (yang universal selalu dicapai atas kerugian penduduk pribumi). Atau menurut Frantz Fanon, salah seorang yang menekuni kajian pos kolonialis, for the native, objectivity is always directed against him. ${ }^{22}$ Dalam pandangan kaum universalisme dan obyektifis ini, selalu ada kemungkinan untuk melakukan aplikasi umum dan di manapun (general aplication) dimana tak ada lagi distingsi antara manusia dan tempat atau lokal tertentu. Oleh karena itu, bicara tentang Islam sebagai obyek kajian yang dipakemkan di Eropa, diyakini bisa juga berlaku di negeri-negeri jajahan terlepas dari soal apakah Islam yang ada di negeri jajahan itu berbeda secara praktis dari pengalaman yang dipakemkan di negeri seberang sana.

Terinspirasi dari kajian Arkoun tentang praktek universalisme Barat terhadap Islam tersebut, maka bicara tentang akar hegemonik dalam Islam radikal ini berarti, bila Islam di Arab bisa dipraktekkan di Afrika dan berlaku sama, maka hal serupa juga bisa terjadi di Asia Selatan, dan juga Asia Tenggara. Singkatnya, bentuk universalisme

${ }^{20}$ Ahmad Baso (makalah), "NU Studies vis-a-vis Islamic Studies: Perspektif dan Metodologi Dari Oleh Dan Untuk Islam Indonesia Pasca 11 September” h. 2. Lihat juga Muhammed Arkoun, "Islamic Studies: Methodologies", dalam John L. Esposito, The Oxford Enciclopedia of the modern Islamic World, (Oxford: Oxford University Press, 1995), vol. 2, h. 332-340. Bandingkan dengan Richard C. Martin (ed), Approach to Islam and Religious Studies, (Tucson: The University of Arizona press, 1985); Azim Nanji (ed), Mapping Islamic Studies: Geneology, Continuity and Change (Berlin: Mouton de Gruyter,1997). Ulasan yang lain mengenai bagaimana publik Barat menggambarkan dalam bentuk yang negatif. Lihat Mohammed Arkoun, (terj. Hasyim Shalih), Membongkar Wacana Hegemonik Dalam Islam dan Postmodernisme, (Surabaya: Al-Fikr, 1999), h. 192.

${ }^{21}$ Edward Said, Power, Politic, and Power: Interview with Edward Said, (edited and with introduction by Gauri viswanathan), (London: Bloomsbury, 2005), h. 111.

${ }^{22}$ Frantz Fanon, The Wretched of the earth, (New York: Penguin Book, 1967), h. 77 . 
Islam yang dipakemkan di Arab oleh Islam radikal bisa juga berlaku sama di negeri negara-negara yang lain dan mengorbankan lokalitas sebagaimana telah berlakunya model ke-Islaman Arab di negerinegeri yang lain.

Dalam kajian tentang dalam sub pembahasan postkolonialis, penting sekali untuk mengungkap tentang bagaimana subyek-subyek yang terpinggirkan itu dan bagaimana ideologi-ideologi bekerja dan diubah. Pentingnya pemahaman tentang realitas lokal menjadi prasyarat agar lahir pemikiran-pemikiran kritis untuk menghadapi ide ide yang akan diuniversalkan. Dari lokalitas itulah ide universal didialogkan, dikritisi, atau bahkan akan ditolak. ${ }^{23}$ Kemudian konsep lokalitas itu diturunkan kembali pada konteks dan situasi lokalnya. Said menelusuri tentang tahap-tahap pembentukan lokalitas, yang mana dari suatu lokus tertentu seringkali lokalitas itu dimigrasikan keluar dalam bentuk tulisan dan wacana yang akhirnya membentuk suatu pakem. Pada saat menjadi pakem inilah ia berpotensi menjadi hegemonik terhadap sesuatu di luar dirinya. Dengan demikian, ia bisa dilemahkan dengan kerja konstruksi subyek terhadap lokalitasnya sendiri yang dipersiapkan untuk menghadapi bahaya masuknya ide universal yang akan diarahkan kepadanya. Pandangan seperti inilah yang kemudian dikenal dengan sebutan "teori travelling" atau "kritik sekuler"24.

Dalam pengertian yang lain bisa dikatakan bahwa dalam konsep "traveling teori" nya Said, lokalitas bisa bermakna ganda. Pada satu sisi, ia bisa dipakai dalam memahami pengetahuan dan teori. di sisi lainya ia bisa dipakai sebagai pisau analisis bagi episteme yang telah mengalami pembakuan untuk di migrasikan menjadi Universal.

${ }^{23}$ Dalam kajian Said tentang Orientalisme, mengilhami sebagian ilmuwan postkolonialis untuk meluaskan penulisan tentang "sejarah dari bawah" dan "menggali" pengalaman-pengalaman mereka yang sampai saat itu telah "tersembunyi dari sejarah". Lihat Ania Loomba, Colonialism/postcolonialism; (New York: Routledge, 2000) terj; Hartono Hadi Kusumo, Kolonialisme/ Pascakolonialisme, (Yogjakarta: Bentang Budaya, 2003), h. 298-299.

${ }^{24}$ Edward Said, "Traveling theory", dalam The World, The Text, and The Critic, (London: Vintage, 1983), h. 226-247. Teori traveling juga disinggung oleh Nyoman Kutha Ratna (cetakan pertama) dalam Buku Postkolonialisme Indonesia; Relevansi Sastra, (Yogjakarta: Pustaka Pelajar, 2008). 
Dalam contoh kasus misalnya, kalau saya menempatkan Osamah Bin Laden sebagai salah seorang Islam radikal dan seorang yang melekat pada dirinya sebagai seorang universalisme, maka sebenarnya ia bukanlah universalis, namun ia seorang intelektual lokal dengan segenap keterbatasannya (teori traveling tahap pertama). Kemudian saya menempatkan pemikiran Osamah dalam konteks dimana dia dibatasi oleh segenap konstruk pengetahuan dan kuasa yang ada di sekitarnya. Sehingga pemikirnya tidak berlaku bagi kita karena kita sudah punya tradisi berfikir sendiri tentang politik dan kultur bangsa kita yang kemudian dari sana kita dialogkan, adaptasikan, dan juga kita pakai untuk mengintervensi maupun resistensi terhadap pemikiran Osamah (teori traveling tahap kedua).

Dalam bahasa yang lebih tajam, dengan "teori traveling" atau "kritik sekuler", keduanya mencoret universalismenya osamah dan membatasinya pada waktu yang bersamaan. Dalam contoh yang sangat lokal misalnya konflik yang berbasis militansi agama ditemukan penyelesainya dengan "kultur lokal" atau kembali pada identitas budaya lokal, seperti dalam kasus kerukunan umat beragama antara Islam dan Katolik di Desa Klepu Kecamatan Sooko Kabupaten Ponorogo. Bukan dengan konsep "universalisme Islam" sebagaimana diusung oleh Islam radikal. Dengan kata lain "Universal" tidak punya arti apa-apa dalam kehidupan keseharian masyarakat dalam persilangan identitas agama, budaya, dan etnik.

\section{Teori Traveling Tahap Pertama dan Kedua: Epistem Lokal Islam Radikal}

Telah dijelaskan pada teorinya Said tentang traveling theori, bahwa setiap wacana lokal ketika dimantapkan dalam bentuk tulisan teks maka ia akan mengalami universalisasi ide (teori traveling tahap pertama). Kemudian, ide universalisasi itu akan diintervensi dan dikritisi dan didialogkan dengan lokalitas (teori traveling tahap kedua). Dalam sub tema ini akan diterapkan proses pembentukan tentang "migrasi" teori dari lokalitas wacana Islam radikal dan selanjutnya akan dikritik ide itu dalam lokalitas Islam pribumi.

Pendekatan yang dipakai dalam teori traveling tahap pertama ini, adalah strategi "pemilahan" antara "pengalaman masa 
kenabian" dan "wacana kenabian". 25

Perbedaan antara "masa kenabian" dan "wacana tentang kenabian" adalah adanya Nabi dan setelah adanya Nabi. Ketika Nabi masih ada, dia disaksikan dan praktek ajaran Islam betulbetul nampak sebagai suatu pengalaman yang hidup dan bersifat menggetarkan ke seluruh penjuru Arab. Pengalaman ke Islaman bersama Nabi hadir dalam sejarah Arab sebagai sesuatu yang bersifat nyata. Sedangkan "wacana kenabian" berada ketika masa Nabi hidup itu sudah usai. Apa yang terjadi pada masa kenabian diwacanakan ulang, disebut-sebut, bahkan diseleksi sesuai dengan hasrat si pembawa berita atau si penutur dalam menceritakan ulang peristiwa pertama. Penceritaan ulang tentang peristiwa kedua yang sudah melewati si penutur inilah Nabi dihadirkan ulang sebagai sebuah wacana. Pada masa kenabian peristiwa itu hanya terjadi sekali seumur hidup sedangkan pada peristiwa kedua umurnya relatif lebih panjang karena pada yang kedua ini bergantung pada emosi dan seringkali ideologi sang penutur dalam menuturkan berita. Jika sang penutur tersebut tergabung dalam institusi tertentu maka tuturan itu berubah menjadi ideologi untuk kebutuhan rekayasa sosial.

Kerja konstruksi pengetahuan tentang wacana kenabian inilah posisi dari universalisme Islam. Jadi pada awalnya masa kenabian adalah masa dari lokalitas Arab tentang pengalaman kenabian. Namun karena ia dikonstruksi oleh sang penutur wacana (Islam radikal) dan dipakai sebagai sebuah model ke-Islaman hari ini maka seolah-olah itu adalah masa kenabian. Padahal pada hakikatnya itu adalah wacana tentang kenabian yang mengalami proses untuk dihadirkan ulang. Namun proses menghadirkan ulang masa kenabian itu tidak lengkap. Manusia punya keterbatasan dalam mengcover seluruh masa kenabian. Adanya keterbatasan itu maka ketika sang penutur membawa berita tentang kenabian

${ }^{25}$ Strategi "pemilahan" ini, penulis terinspirasi dari metodologi pembacaan Muhammad Abed al-Jabiri. Dalam menjelaskan metodologinya ada tiga konsep yang diperkenalkan, yakni Jam' al-Qāri ' an al-Maqru, kemudian Fashl al-Qāri' an alMaqru' dan waṣl al-Qāri 'an al-Maqru. Lihat al-Jabiri, Nahnu wa Turāṣ; Qirā'ah Mu'așșirah fi turāṣina al-Falsafi, (Casablanca: al-Markaz al-Tsaqofi al-'Arabi, 1986), cet. V h. 12-50. Lihat juga Nasr Hamid Abu Zaid, Naqd al-Khitāo ad-Dini, (Mesir: Sina li an-Nasyr, 1994). 
untuk dipraktiskan di zaman sekarang dia akan melakukan seleksi wacana agar tampil serba ideal; ada yang didiamkan, disebut-sebut, ditonjolkan, diulang-ulang bahkan ada yang diabaikan.

Setelah kerja dari konstruksi pengetahuan itu telah dirampungkan, maka muncul proses standarisasi tentang bentuk Islam yang sah. Standarisasi itu seperti Islam yang sesuai dengan al-Qur'an dan Hadis dan hanya bersumber dari keduanya. Lebih parah lagi, itu hanya milik mereka dan ada pada diri mereka (Islam radikal). Pengetahuan yang dipakai oleh Islam tradisional dalam bentuk "kitab kuning" dianggap begitu saja sebagai tidak Qur'ani dan menyimpang dari kenabian. Dengan begitu, mereka para penganut dan pengamal kitab kuning (Islam tradisional) diangap begitu saja sebagai Islam yang bid'ah dan salah serta tersesat. Lebih tampak lagi dalam upaya rekayasa sosialnya bila ada Islam tradisionalis mengangkat satu bentuk tafsir dari al-Qur'an dan hadis tentang adanya keselarasan faham demokrasi dengan Islam, maka akan segera dicap bahwa tafsiranya keliru dan harus diluruskan oleh mereka. Misalnya mereka mencari dalam Islam bahwa demokrasi itu bukan ajaran Islam karena kedaulatan terletak di tangan rakyat dan bukan dari Allah. ${ }^{26}$

Jadi inilah aspek hegemonik dari ide universalisme Islam yang menurut pandangan kaum postkolonial jika diperhadapkan dengan Islam tradisional dalam konstruk pengetahuannya.

Menurut Walter Mignolo, "Project of inter-connection from subaltern perspective and beyond the managerial power and monotopic inspiration of any abstract universal" ${ }^{27}$. Berangkat dari cara pandang Mignolo itu maka kita bisa melihat banyaknya karya yang telah ditulis oleh para sarjana Timur Tengah yang mengangkat ide Islam universal dan telah menjadi bagian dari bagian kehidupan keagamaan di tanah air ini. Banyak isu-isu yang mentereng ber-seliweran di tengah kehidupan para pelajar dan ruang-ruang akademik seperti, khilafah

${ }^{26}$ Taqiyudin An-Nabhani, Nizām al-Islām (Peraturan hidup Dalam Islam). Terjemah oleh Abu Amin dkk., (Jakarta: Hizbut Tahrir Indonesia, 2006), h. 39. Tidak hanya ide demokrasi yang ditolak oleh para ideolog Islam ini, namun juga Nasionalisme, Kapitalisme, Sosialisme, dan termasuk konsep negara. Usulan yang diberikan adalah negara Islam atau daulat Islamiyat.

${ }^{27}$ Walter D. Mignolo, Local Histories/Global Designs: Coloniality, Subaltern Knowledge, and Border Thinking, (Princeton: Princeton University Press, 2000). 
Islamiyah, masyarakat yang Islami, moralitas Islam, busana yang Islami, syari'atisasi kehidupan, dan lainya. Dalam situasi seperti ini maka posisi subyektifitas Islam tradisional sedang ditantang untuk secara kritis memahami konstruk pengetahuan yang sedang dan akan dimapankan.

Dalam kaitan dengan isu tersebut, sebenarnya ada unsuryang harus dikenali di dalamnya, yakni Islam tradisional adalah umat yang menganut dan mengamalkan ajaran serta tradisi yang diwarisi dari Islam zaman pertengahan..$^{28}$ Dan Islam radikal yang mengakui dan membenarkan serta berusaha mendakwahkan ajaranya melalui lingkup ruang-ruang sosial ${ }^{29}$ yang mengasalkan pemahaman atas universalisme Islam itu dari corak pemikiran model Islam zaman Nabi yang penuh toleransi, pluralis, dan humanis. Unsur itu adalah adanya otonomi pengetahuan. Aspek otonomnya adalah konstruksi pengetahuan yang mengasalkan pengetahuan pada masa kenabian itu basis sosialnya telah sirna. Masa itu telah melewati waktu sekian abad lamanya. Dengan demikian pengetahuan itu tidak menggambarkan sama sekali kenyataan sosial yang ada pada masa ini. Basis sosial hari ini telah berubah sama sekali. Dengan adanya hal itu maka konstruksi pengetahuan itu telah mengalami tingkat otonomi dengan realitas yang ada pada masa ini. Bahkan, otonomi itu telah mencapai kadar seratus persen.

\footnotetext{
${ }^{28} \mathrm{Kaum}$ Islam lokal dalam hal ini adalah penganut dan pengamal ajaran ulama Salaf al-Sălih yang hidup pada generasi tabi'in dan tabiin at-tabi'in. Kemudian penjagaan atas tradisi ini terpelihara sampai sekarang, yang mana benteng utamanya adalah "pesantren”. Model pengajaran yang dipakai biasanya bersifat doktrinal-dogmatis yang terpusat pada figur kyai yang kharismatik. Sedangkan Universalisme Islam terpusat di pendidikan kampus sebagai markasnya dan diajarkan dengan media Lembaga Dakwah Kampus atau LDK. Lihat Ahmad Syafi'i Mufid, Perkembangan Faham Keagamaan Transnasional di Indonesia, (Jakarta: Balitbang dan Diklat Kemenag RI, 2011), h. 115.

${ }^{29}$ Penyebaran ide universalisme Islam ini melelui media masjid-masjid yang ada di kampus-kampus umum dan agama. Kasus di surabaya, kampus yang sering dipakai adalah Universitas Air Langga UNAIR, Universitas Negeri Surabaya (UNESA), Institut Teknologi Surabaya (ITS), dan kampus berbasis Agama seperti IAIN. Pemilihan media kampus sebagai tempat penyemaian ide karena asumsinya bahwa para mahasiswa adalah kader yang dianggap mempunyai daya juang dan progresifitas sehingga ide tersebut bisa segera ditularkan kepada yang lain. ibid., h. 115-117.
} 
Adanya bahaya tentang jebakan otonomi pengetahuan itu maka Islam tradisionalis seringkali melakukan taking over atas sebagian konstruksi pengetahuanya sendiri untuk bisa beradaptasi dengan wilayah kesejarahan bumi tempat dia berpijak. Bermanuver dengan menyelami selera agama masyarakat pribumi dengan mengambil dasar dari satu kaidah fiqhiyah yang umum dikalangan mereka yakni, (al-muhāâfaztu 'ala qādim aṣ-Ṣălih wa al-akhżu bi al-jadìd al-aṣlah)..$^{30}$ Sedangkan Islam radikal tetap dalam konstruksinya ala Timur Tengah dengan mengambil unsur-unsur yang dianggap bisa menandingi lokalitas Islam tadisional dibarengi dengan unsur yang dapat menandingi Barat. Unsur itu berangkat dari masa lalu Islam yang jauh dengan tujuan menghadapi tantangan masa kini dan masa depan.

Jika kita mencoba mengikuti alur pemikiran dari Islam radikal ini bentuknya seolah-olah seperti; ketika konflik terjadi antara "unsur lama" dan "unsur baru" dalam suatu konstruksi pengetahuan, maka ada upaya untuk menghimpun kekuatan sosial yang bisa mewakili perjuangan tegaknya unsur lama tersebut atas unsur yang baru. Kekuatan sosial itu dilabeli sebagai masyarakat yang sesuai dengan masa Nabi demi mendapatkan legitimasinya. Ini dilakukan dengan mencari masa lalu, di masa kehidupan Nabi saw "prinsip-prinsip dasar" yang mereka tafsirkan dalam bentuk yang sesuai dengan nilai-nilai baru yang mereka perjuangkan itu. ${ }^{31}$ Pembacaan yang mereka lakukan atas "masa lampau yang jauh" itu

\footnotetext{
${ }^{30}$ Kaidah ini telah umum dipakai oleh kelompok Islam tradisionalis dalam membumikan Islam di Nusantara. Adapun pengambilan Qaidah ini di kutip dari kitab yang menjadi kurikulum penting dalam pengajaran di pesantren. Lihat Imam Jalal ad-Din 'Abd ar-Rahman Abi Bakr as-Suyuti, al-Asybah wa an-Nażāir fi al-Furu' (Semarang: Toha Putra, tth).

${ }^{31}$ Bentuk dari tumpang tindih antara unsur lama dan unsur baru bisa dilihat dalam karya-karya Taqiyudin an-Nabhani, Niz̄ām al-Islam, terjemahan Peraturan Hidup Dalam Islam oleh Abu Amin dkk., (Jakarta: Hizbut Tahrir Indonesia, 2006). An-Nabhani, Ajhizah ad-Daulat al-Khilafah, (Beirut Libanon: Dar al-Ummah, 2005). An-Nabhani, Nizāam al-Ijtima' fi al-Islām cet. IV, (Beirut: Dar al-Ummah, 2003). Ahmad Da'ur, Naqd al-Qanūn al-Madani (ttp: Tp.,1990). Hizb Tahrir, Mafahim Siyasi li Hizbit Tahrir, terj oleh Siddiq al-Jawi cet. IV, (Jakarta: HTI, 2005). Dan lainnya yang tidak kami sebut disini. Beberapa buku tersebut sebagai contoh bagaimana unsurunsur baru diletakkan di atas unsur lama.
} 
tampakseakan-akan memberi dasar baru bagi "unsur baru" tersebut. ${ }^{32}$ Masa kini yang berada di sini dan hari ini dipandang dengan masa lalu itu dan dibuat seakan-akan menyimpang dan tidak asli. Dengan alur itu maka hari ini mendapatkan legitimasinya untuk dicela, dikutuk, dan bahkan dimaki. Namun pada dasarnya dasar makian dan celaan itu untuk membangun masa depan tapi atas nama masa lalu.

\section{Identitas Etnis Islam Nusantara Dan Bentuk dari kultur lokal Islam Tradisional.}

Makalah yang singkat ini tentu tidak cukup untuk mengungkap dan menunjukkan secara menyeluruh masalah identitas etnis dan variasinya yang dimaksudkan dalam sub tema di atas. Namun ada satu tipe yang bisa saya jadikan contoh yang mungkin bisa menginspirasi kasus lainya tentang masalah identitas etnis tersebut. ${ }^{33}$

Bentuk asli dan nyata dari Islam tradisional adalah tampak dari sejumlah kyai Nahdlatul 'Ulama yang ada di pesantrenpesantren di bumi Indonesia. Kepribadian dan karakter mereka tidak dibentuk oleh lembaga formal seperti Perguruan Tinggi. Mereka juga bukan murid dari guru besar. Mereka adalah murid dari para kyai dan ulama pendahulu dan berasal dari pesantren yang

\footnotetext{
${ }^{32}$ Misalnya dalam tulisan an-Nabhani, Nidlom al-Islam...h. 9. Dalam buku tersebut dikatakan, "pemecahan yang benar terhadap masalah tidak akan ditempuh kecuali dengan fikr al-mustanir (pemikiran yang cemerlang) tentang alam, manusia dan hidup. Karena itu bagi mereka yang menghendaki kebangkitan dan menginginkan kehidupan pada jalan yang mulia (Islam) mau tidak mau mereka harus memecahkan problematika pokok tersebut dengan benar, yakni melalui berfikir cemerlang tadi. Pemecahan inilah yang menghasilkan akidah dan menjadi landasan berfikir yang melahirkan setiap pemikiran cabang tentang perilaku manusia di dunia ini serta peraturan-peraturanya".

${ }^{33}$ Kembali pada tradisi dan identitas kultural yang berbasis pada lokalitas dalam berteori ini terinspirasi dari kajian studi post kolonialis yang dilakukan oleh Ania Lomba dalam bukunya Colonialism/postkolonialism..h. 298-299. Diterjemahkan oleh Hartono Hadikusumo. Dalam kajian subaltern yang ada buku tersebut diungkapkan, "penting sekali untuk mengungkap dan menulis "sejarah dari bawah" atau menggali pengalaman-pengalaman kelompok yang "tersembunyi dari sejarah". Penulisan seperti ini penting sekali untuk mengungkapkan dan memberi konsep yang jelas akan suatu identitas lokal. Jika gambaran lokalitas atau identitas etnis ini ditemukan dan bisa digambarkan akan bisa ditemukan pula konsep apa saja yang menghegemoninya.
} 
ilmunya diwariskan secara ber-sanad. Kebesaran mereka muncul dari hasil interaksi dan berjumpa setiap hari dengan masyarakat lokal dan hidup ditengah-tengah mereka dengan berbagai problem yang mengitarinya. Para kyai itu adalah "produk pribumi" yang tercipta dari masyarakat itu sendiri. Sikap dan gayanya yang khas adalah corak asli dari wajah Islam yang telah bertaut dengan kultur lokal. Cara hidup yang bersahaja, seperti memakai sarung, kopyah dan cara baca kitab kuning yang khas ala pribumi, polos dan apa adanya, kadang dianggap sebagai keluar dari normalitas dan batasbatas norma yang ada pada masyarakat modern.

Namun dibalik karakternya yang khas itu, ia mengolah dan meracik gaya ke-Islaman yang sudah "dipakemkan" di Timur Tengah sana untuk "diracik" agar sesuai dengan selera dan rasa lokal ala penduduk pribumi. Pada sisi yang lain mereka juga menjadi benteng bagi masuknya modernitas. Mereka juga melakukan peracikan ulang modernitas ala Barat agar modern tapi modernitas itu ala budaya pribumi. Sikap dan gaya yang diambil para kyai itu sebenarnya menempatkan dia pada posisi dua arah. Misalnya cara kyai memberi makna demokrasi, dalam arus kemodernan yang dipakemkan di dunia Barat, dan mengisinya dengan praktek ritual istighosah akbar di senayan ala pribumi, yang merupakan jenis ritual dan ibadah yang telah mengalamai pengawinan antara ke-Islaman Timur Tengah dan pribumi, sesuai dengan pemahaman yang mereka miliki.

Perilaku kyai yang lain tampak sekali pada proses pergulatan krisis politik Indonesia dalam rangka reformasi menuju proses demokrasi. Masa itu menjamur elemen-elemen civil society yang menggerogoti otoritas negara. Para tokoh berebut untuk mendapat gelar menjadi sang reformis dan pendekar demokratis. Kelompok sosial di masyarakat yang terdiri dari lembaga sosial masyarakat, partai, dan organisasi lainya menjadi mendadak kritis terhadap negara. Arus besar itu malah menggiring Abdurrahman Wahid, dengan gaya politik dan menuver yang sering dilakukanya, melakukan aksi yang justru berlawanan arus dengan gelombang besar reformasi tersebut. Dia menembus batas dengan cara melakukan rekonsisiliasi dan komunikasi kultural pada elit politik 
yang jadi sasaran kritik semua elemen masyarakat. ${ }^{34}$ Apa maknanya? Ketika negara sangat represif terhadap kebebasan masyarakat untuk berpendapat, dan semua elemen bangsa takut untuk berbicara kritis, Wahid membentuk forum demokrasi sebagai pendakwah kebebasan. Namun ketika kran politik dibuka dan kebebasan berpendapat diberi ruang, Wahid justru mendampingi presiden Soeharto yang menjadi sasaran kritik semua orang. Dalam gerak manuver itu seolah ada makna yang disampaikan bahwa "orang lemah harus didampingi walaupun dia memusuhi kita saat dia sedang berkuasa".

Dasar dari tradisi keilmuan kyai yang disebut dimuka sebagai "identitas etnis keberislaman pribumi" adalah pertautan segitiga antara Aqidah atau Tauhid, Syari'ah dan Fiqh, serta Tasawuf secara berkelindan. Dalam praktek jangka panjangnya, akan mengikatkan mereka pada dimensi duniawi dan ukhrowi sekaligus. Salah satu ungkapan yang bisa diperdengarkan secara sayupsayup dari para Kyai adalah "hidup di dunia adalah sarana untuk mencapai kehidupan akhirat, dan akan kehilangan maknanya bila tidak diperlakukan seperti itu". Pertautan antara dimensi dunia dan akhirat dalam tradisi keilmuan kyai ini merupakan inti dasar bagi pertahanan untuk berhadapan dengan tantangan sekularisme yang sudah terang-terangan yang ditimbulkan dari modernisasi dan Islam radikalis. Pertautan dimensi duniawi-ukhrowi ini tidak memungkinkan pandangan dunia yang hitam putih dan penolakan mutlak pada kehidupan dunia. Dengan kata lain, seburuk-buruk kehidupan duniawi haruslah dijalani dengan penuh kesungguhan dan ketulusan. Pada figur kyai inilah, "identitas etnis" Islam tradisional itu ditemukan konsepnya. Sesuatu yang khas yang ada di tanah air kita yang tidak bercorak Barat dan tidak pula ala Timur Tengah (la syarqi wa la ghorbi).

\section{E. Problem Otoritas Islam Radikal dan Islam Tradisional}

Namun bila kita hanya memfokuskan pada perbandingan dua model wacana Islam di atas, akan ada bahaya tersendiri. Utamanya faktor-faktor formasi "diskursif” yang melahirkan konflik antara "unsur lama" dan "unsur baru”. Bahkan bisa jadi faktor

${ }^{34}$ Zainal Arifin Thoha, Jagadnya Gus Dur: Demokrasi, Pluralisme, dan Pribumisasi Islam, (Yogjakarta: Kutub, 2010), h. 40-42. 
internal wacana tersebut merupakan hal yang bersifat sekunder dan bukan faktor primernya. Hal itu dikarenakan, wacana tersebut masih menapak pada proses pembentukanya, atau dalam kata lain masih pada proses "pra sejarahnya". Ada faktor luar yang sedang mengancam mengiringi proses-proses wacana keagamaan di tanah air ini. Misalnya seperti adanya invasi bangsa Eropa dalam berbagai bentuknya dalam aspek ekonomi dan sosial. Bisa jadi faktor luar ini merupakan hal yang utama. Ancaman ekspansi ekonomi politik dan budaya dari bangsa Barat yang semakin menguat dan mengancam dibarengi dengan keadaan sosial ekonomi dan politik tanah air Indonesia yang semakin tidak jelas. Penegakan hukum yang tidak kunjung mendapatkan kepastian. Tingkat inflasi yang tinggi, kemiskinan, dan angka pengangguran tambah meningkat, pendapatan yang rendah, dan akses kebutuhan yang semakin susah untuk dijangkau. Dalam posisi ini Barat tampil seolah-olah menjadi dua muka sekaligus. Di satu sisi, ia mewakili sebagai lawan yang punya sifat-sifat mendominasi, menghegemoni, dan menjajah. Sedang sisi lainnya, ia menampilkan diri sebagai sebuah idealitas dari impian akan kejayaan dengan segenap nilai-nilai dan unsur materialnya, seperti tehnologi, demokrasi, kebebasan dan sebagainya. Di sini Barat bagi kita tak ubahnya seperti musuh yang harus diwaspadai, tapi di sisi lainya juga sebagai tauladan yang menggoda untuk diikuti dan dipanuti (uswat al-hadloroh).

Barat sebagai bangsa yang telah maju dan kehadirannya yang terus menerus melingkupi kesadaran dan pemikiran bangsabangsa timur menjadikan mereka timbul perasaan terhimpit akan laju cepatnya kemajuan mereka. Perasaan terhimpit itu menjadikan relasi tegaknya unsur lama dan unsur baru itu terasa semakin keras. Demikianlah peran dari faktor luar pada level kesadaran dan pemikiran masyarakat pribumi. Namun relasi unsur baru dan lama itu hubungannya lebih mirip seperti "jalan di tempat". Disinilah konflik otoritas terjadi. Sebagaian kelompok merujuk ke tradisi masa lalu sebagai otoritas yang harus diperjuangkan dan sebagian lagi langsung menjadikan Barat sebagai acuan dan otoritas bagi tauladan masa depan. Dalam kerangka ini Islam tradisional lahir sebagai bentuk Islam yang keluar dari dua mainstream tersebut. Dia lahir dari pribumi yang mengalir dari dua arus model pemikiran 
sembari mengambil madu dari dua arus utama tersebut. Ia tidak tampil berhadap-hadapan dengan Barat tapi di sisi yang lain tetap mengambil unsur lama yang dimodifikasi ala pribumi. Namun walau demikian, bentuknya yang ada di masa ini masih menjadi pergulatan pemikiran yang belum usai.

Bagi kelompok Islam radikalis, adanya bentuk kehadiran bangsa Barat di bumi tanah air merupakan bentuk problematika sendiri. Karena pada kenyataanya, tradisi "salaf" yang telah mendarah daging serta mengurat nadir tetap hidup dalam jiwa, perasaan, persepsi, ingatan, dan harapan-harapan mereka. Sehingga dengan datangnya peradaban Barat itu, mereka terasa seperti memikul beban tradisi yang selama ini hidup di dada mereka menjadi semakin berat dan menyesakkan. Akibatnya muncul reaksireaksi yang radikal karena beratnya beban memikul tradisi yang menghimpit pada diri mereka.

\section{F. Kesimpulan}

Dari pemaparan makalah ini maka ada beberapa hal yang bisa ditarik kesimpulan sebagai berikut:

Pertama, sisi hegemonik yang ada pada Islam radikal adalah konstruksi pengetahuanya yang mencoba melakukan pembakuan atas model ke-Islaman sebagaimana yang ada pada masa Nabi. Aspek hegemoniknya terletak pada obyektifikasinya terhadap Islam tadisional sebagai model Islam yang tidak asli dan otentik.

Kedua, ada perbedaan yang dirancukan oleh para Islam radikalis tentang masa kenabian dan wacana kenabian. Islam masa kenabian ada pada waktu Nabi masih hidup yang pengalaman itu menggetarkan ke seluruh penjuru Arab dan hanya terjadi sekali seumur hidup. Sedangkan wacana kenabian adalah Nabi dihadirkan ulang melalui wacana. Di tangan para penutur wacana ini masa kenabian dihadirkan sebagai konstruksi wacana yang ada muatan rekayasa sosialnya.

Ketiga, kritik atas wacana kenabian itu ada pada konsep Islam pribumi. Identitas dari Islam ini mewujud dalam bentuk kyai.

Keempat, faktor luar wacana, yakni kehadiran bangsa Barat sebagai bentuk nyata akan kemajuan menimbulkan perbedaan 
mainstream ke-Islaman hari ini. Islam radikal mengambil posisi berhadapan dengannya. Aspek yang menarik dari Islam pribumi dalam kerangka ini adalah mengalir dalam dua arus tanpa hanyut dari salah satu aliranya. Dengan sikap seperti ini maka Islam pribumi adalah model ke-Islaman yang tidak timur dan tidak pula Barat (lā syarqi wa lä gharbi).[]

\section{Daftar Pustaka}

Adonis, Aś-Sābit wa al-Mutahawwil: Bahts fi al-Ibda' wa al-Itba' 'Inda al'Arab yang sudah di terjemahkan ke bahasa Idonesia dengan judul Arkeologi sejarah pemikrian Arab Islam, Yogyakarta: LkiS Group, 2007.

Abu Zaid, Nasr Hamid, Naqd al-Khitab al-Dini, Mesir: Sina li an-Nasr, 1994.

Arkoun, Muhammad, Terj. Hasyim Shalih, Membongkar Wacana Hegemonik Dalam Islam dan Postmodernisme, Surabaya: Al-Fikr, 1999.

Baso, Ahmad, "NU Studies vis-a-vis Islamic Studies: Perspektif dan Metodologi Dari Oleh Dan Untuk Islam Indonesia Pasca 11 Septemer". Makalah, tidak diterbitkan.

Bertens, Karl, Filsafat Barat Abad XX Prancis jilid II, Jakarta: Gramedia Pustaka Utama, 1996.

Budiman, Kris, "Hermeneutika dan Kebudayaan Sebagai Teks: Persoalan Etnosentrisme Dalam Interpretasi”, Makalah, tidak diterbitkan.

Da’ur, Ahmad, Naqd al-Qanūn al-Madani, ttp: tp,1990.

Eriyanto, Analisis Wacana; Pengantar Analisis Teks Media, Yogjakarta: LKiS, 2005.

Esposito, John L., dan O. Voll, John, Demokrasi Di Negara-Negara Muslim; Problem dan Prospek, Bandung: Mizan, 1999.

, The Oxford Enciclopedia of the modern Islamic World, Oxford: Oxford University Press, 1995.

Fanon, Frantz, The Wretched of the earth, New York: Penguin Book, 1967. 
Foucault, Michel, The archeology of Knowledge; terj. A.M. Sheridan Smith, London: Tavistock, 1972.

al-Jabiri, Muhammad Abed, al-Khithob al-Arob al-Mu'ashir: Dirosath Tahliliyah Naqdiyah, Beirut: Markaz Dirosah al-Wihdah al Arobiyah, 1992.

—., Nahnu wa Turots; Qiro'ah Mu'ashirah fi turatsina al-Falsafi, Casablanca: al-Markaz al-Tsaqofi al-'Arabi, 1986.

Kurzman, Charles, (ed), Wacana Islam Liberal; Pemikiran Islam Kontemporer Tentang Isu-Isu Global, Jakarta: Paramadina, 2001.

Loomba, Ania, Colonialism/postcolonialism; New York: Routledge, 2000. terj; Hartono Hadi Kusumo, Kolonialisme/ Pascakolonialisme, Yogjakarta: Bentang Budaya, 2003.

Madjid, Nurcholish, Islam Doktrin dan Peradaban, Jakarta: Paramadina, 2005.

Martin, Richard C., (ed), Approach to Islam and Religious Studies Tucson: The University of Arizona press, 1985.

Mignolo, Walter D., Local Histories/Global Designs: Coloniality, Subaltern Knowledge, and Border Thinkin, Princeton: Princeton University Press, 2000.

Mufid, Ahmad Syafi'i, Perkembangan Faham Keagamaan Transnasional di Indonesia, Jakarta: Balitbang dan Diklat Kemenag RI, 2011.

Mulkan, Abdul Munir dengan Abdala, Ulil Absor tema "Islam adalah Produk Lokal” yang muat di situs internet pada tanggal 14 April 2002 .

An-Nabhani, Taqiyudin, Ajhizah ad-Daulat al-Khilafah, Beirut Libanon: Dar al-Ummah, 2005.

Nanji, Azim, (ed), Mapping Islamic Studies: Geneology, Continuity and Change, Berlin: Mouton de Gruyter,1997.

Nasution, Harun, Islam Rasional, Bandung: Mizan, 1996.

Permata, Ahmad Norma (ed), Agama dan Terorisme, Surakarta: Muhammadiyah University Press, 2006.

Ratna, Nyoman Kutha, Postkolonialisme Indonesia; Relevansi Sastra, Yogjakarta: Pustaka Pelajar, 2008.

Recoeur, Paul, Hermeneutics and The Human Sciences: Essays on language, 
action, and intepretation, terj. John B. Thompson, Cambridge: Cambridge University Press, 1984.

_-, Nizām al-Ijtima' fi al-Istām, cet ke IV, Beirut: Dar al-Ummah, 2003. Terjemahan dengan judul Sistem pergaulan Dalam Islam, Jakarta: HTI Press, 2006.

Said, Edward, Power, Politic, and Power: Interview with Edward Said, edited and with introduction by Gauri viswanathan, London: Bloomsbury, 2005.

- - Representations of the Intellectual the 1993 Reith Lectures, New York: Vintage Books, 1996.

- The World, The Text, and The Critic, London: Vintage, 1983.

as-Suyuti, Jalal Ad-Din 'Abd ar-Rahman Abi Bakr, al-Asybah wa anNadloir fi al-Furu', Semarang: Toha Putra, tth.

Tahrir, Hizbi, Mafahim Siyasi li Hizbit Tahrir terj oleh Siddiq al-Jawi, Jakarta: HTI, 2005.

Thoha, Zainal Arifin, Jagadnya Gus Dur: Demokrasi, Pluralisme, dan Pribumisasi Islam, Yogjakarta: Kutub, 2010.

Tiffin, C. dan Lawson, A., De-scribing empire, Postcolonialism and Textuality, London and New York: Routledge,1994.

Wahid, Abdurrahman, Islam Kosmopolit: Nilai-Nilai Indonesia dan Transformasi Kebudayaan, Jakarta: The Wahid Institut, 2007.

Wahid Institut, Seri Agama dan Konflik 2; Agama dan Pergeseran representasi: Konflik dan Rekonsiliasi di Indonesia, Jakarta: The Wahid Institut, 2009.

Wijaya, Aksin, "Peta Gerakan Islam Di Indonesia", makalah tidak diterbitkan.

- Menusantarakan Islam; Menelusuri Jejak Pergumulan Islam yang tak Kunjung Usai di Nusantara, Yogyakarta: Nadi Pustaka, 2012. 